\title{
An empirical exploration of the role of marketing in forestry education
}

\author{
by Dorothy A. Paun ${ }^{1}$ and Steven R. Shook ${ }^{1}$
}

Forest products managers indicate that it is important for college graduates to have an understanding of marketing in order to be competitive in the workplace. This research, in part a replication of a study completed 30 years ago, was conducted to elicit information that would be useful to faculty, students, administrators, and managers concerning the current role of marketing in forestry schools. A questionnaire was sent to 443 forestry professors at universities in the United States, Canada, and Mexico. Two interesting findings include the apparent existence of a misconception about the functions of economics and marketing in forestry education, and, although industry consistently calls for more marketing emphasis in forest products curricula, these results suggest that forestry schools could do much more to meet this need by encouraging and funding forest products marketing programs.

Key words: marketing, forest education
Les gestionnaires de produits forestiers indiquent qu'il est important pour les gradués de niveau collégial de comprendre ce qu'est le marketing de façon à être compétitif sur le marché du travail. Cette recherche, en partie une réplique d'une étude effectuée il y a 30 ans, a été entreprise afin de souligner l'information qui serait utile aux professeurs, aux étudiants, aux administrateurs et aux gestionnaires et relative au rôle actuel du marketing dans les écoles de foresterie. Un questionnaire a été acheminé à 443 professeurs de foresterie dans des universités américaines, canadiennes et mexicaines. Parmi les résultats, on retrouve deux points touchant premièrement l'existence apparente d'une mauvaise conception des fonctions des sciences économiques et du marketing au sein de la formation en foresterie, et deuxièmement même si l'industrie fait appel constamment à plus d'emphase sur le marketing parmi les programmes de produits forestiers, que les écoles de foresterie pourraient plus adéquatement combler ces besoins en encourageant et en finançant les programmes de marketing de produits forestiers.

Mots clés: marketing, formation en foresterie

\section{Introduction}

Using innovative marketing strategies has become an important tool for firms seeking to enhance their competitiveness due to increased international competition and customer demand for greater product value. The forest products industry has been emerging from a production orientation to a market orientation (Slater and Narver 1994); therefore, it is not surprising that the forest products industry strongly encourages students to secure marketing knowledge and training. Criticism exists in the industry as to whether forestry curricula offer university students the ability to acquire a core knowledge of forest products marketing, as well as knowledge of several other business concepts. Such criticism is not a new phenomenon; over seven decades ago Forbes (1920) wrote "courses in business training are a step in the right direction...giving the forester a proper perspective."

Several surveys have found that the forest products industry in the United States assigns high priority to hiring employees with marketing training (Bowyer 1991; Bratkovich and Miller 1993; Cassens and Bradtmueller 1996; Fischer and O'Leary 1988). Calls for forestry curricula change are not unique to the United States, however. In an assessment of changes needed in Canadian forestry schools, it was stressed over a decade ago that "there should be an increased emphasis on the fundamentals of business, commerce, and marketing" (Nordin 1984). More recently, Tom Buell, as Chairman of the Board of Weldwood

\footnotetext{
${ }^{1}$ Assistant Professor and Ph.D. Candidate, Forest Products Marketing, College of Forest Resources, Department of Forest Products and Engineering, University of Washington, Box 352100, Seattle, Washington 98195-2100, USA. The study was funded by the Center for International Trade in Forest Products, University of Washington, Seattle, Washington, 98195-2100, USA.
}

Canada, indicated that "One thing is certain. There will be an increasing demand and great opportunity for professional foresters in industry and we must market this opportunity to the best candidates that we can find. University curriculae have not kept pace with this change....Economics and business related curriculum content continues to be very important. Over $60 \%$ of our most senior managers are foresters. We also need articulate technically competent marketing executives with professional forestry backgrounds" (Naysmith and Crichlow 1995).

Thirty years ago, Rich (1966) reported that forest products marketing was important because "marketing is the [only] incomeproducing side of a business." The focus of this study is to first replicate Rich's research so as to provide a longitudinal dimension of the role of marketing in forestry education over the past thirty years. Secondly, to offer new insights to educators and industry practitioners, this research is conceptually broadened to include new variables relevant in today's business environment. Such new variables include educators' perceptions on a variety of business disciplines (e.g., international business, finance, strategy); changes in forest products marketing knowledge and associated drivers of such changes; student access to marketing courses outside of forestry schools; satisfaction with students' knowledge of forest products marketing; and educators' perceptions of employer satisfaction with students' forest products marketing knowledge.

\section{Research Methodology \\ Questionnaire Design and Pretest}

The questionnaire was first pretested using 11 forestry, forest products marketing, and marketing professors, as well as several graduate students, to assess the questionnaire's clarity and comprehensiveness. Their suggestions were incorporated 
Table 1. Sampling profile and demographic profile of forestry professors included in the sample

\begin{tabular}{|c|c|c|c|c|}
\hline & Canada & Mexico & United States & Total \\
\hline Number of schools included in sample & 6 & 9 & 48 & 63 \\
\hline Number of schools returning faculty lists & 6 & 4 & 48 & 58 \\
\hline Number of professors sent questionnaires & 58 & 23 & 362 & 443 \\
\hline Number of professors returning questionnaires & 27 & 4 & 207 & 238 \\
\hline Number of unusable questionnaires received & 0 & 0 & 34 & 34 \\
\hline Mean number of students on campus & 23,920 & 5,000 & 22,822 & 22,777 \\
\hline Mean number of students in discipline program & 236 & 128 & 180 & 187 \\
\hline \multicolumn{5}{|l|}{ Number of respondents with job titles of: } \\
\hline Extension Specialist & 0 & 0 & 3 & 3 \\
\hline Lecturer & 1 & 0 & 3 & 4 \\
\hline Research Associate & 0 & 1 & 8 & 9 \\
\hline Adjunct Professor & 0 & 0 & 6 & 6 \\
\hline Assistant Professor & 6 & 0 & 32 & 38 \\
\hline Associate Professor & 8 & 0 & 49 & 57 \\
\hline Professor & 12 & 3 & 72 & 87 \\
\hline \multicolumn{5}{|l|}{ Mean time $(\%)$ reported on: } \\
\hline Teaching & 38 & 21 & 35 & 35 \\
\hline Research & 37 & 49 & 40 & 40 \\
\hline Administration & 19 & 25 & 9 & 11 \\
\hline Extension Activities & 5 & 6 & 15 & 13 \\
\hline Consulting & 2 & 0 & 1 & 1 \\
\hline
\end{tabular}

into a second draft of the questionnaire. A second pretest was then conducted using eight forestry professors and forest products industry practitioners; incorporating their insights and comments resulted in a final four-page questionnaire. The questionnaire consisted of 27 questions; seven questions replicated those used by Rich (1966), while the remaining 20 questions were developed specifically for this study. Most questions utilized a seven-point Likert rating scale.

The questionnaire began with a qualifying question asking the degree to which marketing topics are discussed in the courses taught by the respondent. If professors indicated that marketing is discussed in their courses, they were asked to complete the entire questionnaire. Professors who said they did not discuss marketing were asked to answer only questions eight through 27 . This was done because questions two through seven were not relevant if professors did not discuss any marketing topics in their courses. These questions covered the following: methods and materials used in teaching forest products marketing; specific marketing issues discussed; degree to which students take marketing courses outside of the forestry school; how forest products marketing is covered in courses; and whether subcategories of marketing, such as developing new products, were discussed in courses. The purpose of these questions are to capture the depth of marketing exposure in courses.

All professors, regardless of whether they did or did not discuss marketing topics, were asked to answer questions eight through 27. The intent was to compare the responses of the marketing (professors who discuss forest products marketing topics in their courses) and nonmarketing (professors who do not) groups of respondents. These questions covered the following: importance of students having business training in various business areas such as marketing, accounting, economics, finance, international business, human resources, production, and strategy; satisfaction with students' knowledge of business; perceptions of employers' assessment of the importance of business training; changes in forest products marketing knowledge over the past three years and associated drivers behind such changes; perceptions of the amount of forest products knowledge that will be acquired in the future; student access to marketing courses outside of forestry schools; satisfaction with students' knowledge of forest products marketing; and employer satisfaction with students' knowledge of forest products marketing. The remaining questions covered sample characteristics such as the size of the academic institution, job title, and number of students.

\section{Sample characteristics}

This study replicated the sample that was used by Rich (1966), where professors from four-year forestry programs located in Canada and the U.S. were surveyed ( 92 professors from 47 schools and colleges). However, Rich's sampling frame was extended to include Mexican forestry schools. In total, this sample included 63 departments, schools, and/or colleges of forestry in Canada, Mexico, and the U.S.; hereafter "forestry schools," 6 are Canadian, 9 are Mexican, and 48 are U.S.

To determine which professors would receive questionnaires, requests were sent to each institution requesting faculty rosters. Institutions failing to respond to the original request were contacted first by letter and later by telephone, with the exclusion of the forestry schools in Mexico. Due to the inaccessibility of telephone numbers, Mexican schools were sent an original request written in English and two follow-up requests in Spanish. In total, 58 of the 63 academic institutions provided faculty rosters; $100 \%$ for Canada, $44 \%$ for Mexico, and $100 \%$ for the U.S.

Following Rich's sampling procedure, which "consisted of all professors who taught courses which might conceivably include some marketing" (1966), professors of forest economics, forest management, forest products, forest products marketing, general forestry, industrial forestry, industrial operations, natural resource economics, operations research, pulp and paper sciences, resource policy, urban forestry, and wood science and technology were surveyed. In total, 443 professors met the sampling frame criteria. Each professor was sent a letter explaining the research, a questionnaire, and a return envelope. Professors failing to reply within one month were sent a follow-up letter and questionnaire. 
Table 2. Discipline profile of forestry professors included in the sample

\begin{tabular}{|c|c|c|c|c|}
\hline Discipline area $^{1}$ & $\begin{array}{c}\text { Number of } \\
\text { respondents not } \\
\text { discussing forest } \\
\text { products } \\
\text { marketing in } \\
\text { their courses } \\
\end{array}$ & $\begin{array}{c}\text { Number of } \\
\text { respondents } \\
\text { discussing forest } \\
\text { products marketing } \\
\text { in their courses } \\
\text { (mean extent score }{ }^{2} \text { ) }\end{array}$ & $\begin{array}{c}\text { Number of } \\
\text { nonrespondents } \\
\text { and discarded } \\
\text { questionnaires } \\
\text { uㅏ. }\end{array}$ & $\begin{array}{l}\text { Row } \\
\text { total }\end{array}$ \\
\hline $\begin{array}{l}\text { Forest products, wood science and technology, } \\
\text { wood and timber engineering }\end{array}$ & 42 & $\begin{array}{c}30 \\
(4.00)\end{array}$ & 79 & 151 \\
\hline Forest economics, natural resource economics & 23 & $\begin{array}{c}30 \\
(4.20)\end{array}$ & 57 & 110 \\
\hline Forest management, general forestry, agroforestry & 14 & $\begin{array}{c}13 \\
(3.69)\end{array}$ & 28 & 55 \\
\hline Pulp and paper sciences, wood chemistry & 7 & $\begin{array}{c}3 \\
(5.00)\end{array}$ & 28 & 38 \\
\hline $\begin{array}{l}\text { Forest engineering, timber harvesting and } \\
\text { mechanization }\end{array}$ & 4 & $\stackrel{6}{(4.17)}$ & 21 & 31 \\
\hline Operations research & 5 & $\begin{array}{c}8 \\
(3.75)\end{array}$ & 6 & 19 \\
\hline Forest products marketing & 1 & $\begin{array}{c}8 \\
(6.13)\end{array}$ & 6 & 15 \\
\hline Urban forestry & 2 & $\begin{array}{l}0 \\
-\end{array}$ & 8 & 10 \\
\hline Forest policy, sociology, tourism & 1 & $\begin{array}{c}2 \\
(2.50)\end{array}$ & 4 & 7 \\
\hline Industrial forestry operations & 3 & $\stackrel{2}{(4.00)}$ & 2 & 7 \\
\hline Column total & 102 & 102 & 239 & 443 \\
\hline
\end{tabular}

A total of 238 questionnaires were received, yielding a response rate of $54 \%$. Accounting for disqualified questionnaires (e.g. retired professors), 204 usable surveys were received, for an effective response rate of $46 \%$. Of the 204 usable questionnaires, 102 , or $50 \%$, were from professors who discussed marketing topics in their courses; hereafter, these professors are referred to as the "marketing group" or Group A. The remaining 102 usable questionnaires, or $50 \%$, were from professors who did not discuss marketing topics; hereafter, these professors are referred to as the "nonmarketing group" or Group B. Tables 1 and 2 display the characteristics of the sample.

Armstrong and Overton's (1977) nonresponse methodology was employed to compare early versus late respondents in order to evaluate potential nonresponse bias. Comparing responses of early and late respondents using the two-tailed $t$-test with an alpha of 0.05 suggests that nonresponse bias does not significantly influence the results.

\section{Major Findings \\ Marketing Group}

The research results presented in the following sections report the responses of professors who indicated that they discuss marketing topics in their courses.

\section{Marketing in forestry curriculum}

When asked how forest products marketing is taught at their institutions, $20 \%$ of the respondents indicated that it is a separate course of its own. It is interesting that the percentage of professors indicating that a forest products marketing course is the vehicle for covering marketing topics is similar those reported in 1966 (Table 3), when $22 \%$ of professors reported that autonomous forest products marketing courses were taught. Another $53 \%$ of the respondents indicated that rather than having a separate course in forest products marketing, marketing is discussed in courses such as forest economics, forest management and industrial forestry.

\section{Topic areas covered}

As summarized (Table 4), there is an overall increase in the percent of marketing topics taught, relative to respondents in 1966. The most dramatic changes in course content include an increase in the number of professors reporting that they discuss product planning, developing new products, pricing strategies, and marketing research. Perhaps this suggests that professors are attempting to better prepare students for the intense competitive realities faced by the forest products industry. Another interesting finding is that the social and governmental 


\begin{tabular}{|c|c|c|}
\hline \multirow[b]{2}{*}{ Type of course } & \multicolumn{2}{|c|}{ Percentage of respondents } \\
\hline & 1966 & 1994 \\
\hline Forest economics & 63 & 42 \\
\hline Forest products & 47 & 53 \\
\hline $\begin{array}{l}\text { Forest products marketing } \\
\text { or merchandising }\end{array}$ & 22 & 20 \\
\hline $\begin{array}{l}\text { Forest management, forest business } \\
\text { management }\end{array}$ & 11 & 24 \\
\hline Industrial forestry & 7 & 17 \\
\hline Introduction to forestry ${ }^{2}$ & NA & 10 \\
\hline $\begin{array}{l}\text { Other (logging, milling, policy, } \\
\text { and utilization) }\end{array}$ & 6 & 3 \\
\hline & $n=72$ & $n=102$ \\
\hline
\end{tabular}

${ }^{1}$ Column totals exceed $100 \%$ due to multiple responses.

${ }^{2}$ Course not included in 1966 study.

\begin{tabular}{lccc}
\hline Table 4. Extent to which marketing topics are discussed & \\
\hline & $\begin{array}{c}\text { Percentage of } \\
\text { respondents }\end{array}$ & $\begin{array}{c}\text { Mean } \\
\text { response }{ }^{2}\end{array}$ \\
\cline { 2 - 3 } & $1966 \quad 1994$ & 1994 \\
\hline
\end{tabular}

General conditions

Economics of market demand and pricing; economic factors affecting marketing

Historical background affecting marketing

Technical factors affecting marketing

Social/governmental environment

affecting marketing

$\begin{array}{lll}60 & 83 & 3.91 \\ 46 & 81 & 3.39 \\ 45 & 86 & 3.94 \\ 43 & 88 & 4.03\end{array}$

Institutions and allied areas

Distribution channels; wholesalers and retailers

Foreign trade

Transportation

$\begin{array}{lll}57 & 66 & 2.89 \\ 55 & 81 & 3.60 \\ 54 & 77 & 3.34\end{array}$

Managerial Functions

Advertising and promotion

Company pricing strategy

Company marketing organization structure

Product planning; development and new products

Marketing research and customer buying habits

Personal selling and sales activities

\begin{tabular}{cccc} 
& 19 & 67 & 2.94 \\
& 18 & 56 & 2.53 \\
10 & 39 & 2.04 \\
\hline & $n=72$ & $n=102$ & $n=102$ \\
\hline
\end{tabular}

Column totals exceed 100 percent due to multiple responses.

${ }^{2}$ Mean response based on a Likert scale anchored on 1 or "never discuss" to 7 or "discuss extensively."

environmental issues affecting forest products marketing is the most extensively discussed topic. With a reported mean of 4.03 on a seven-point scale anchored on 1 or "never discussed" to 7 or "discussed extensively," the social and governmental environment received the highest ranking in terms of the extent to which it is discussed in the classroom. This is in contrast to the 1966 study, where the social and governmental environment is ranked seventh out of 13 topics. The increased emphasis on social and governmental environment factors on marketing is understandable in light of the ongoing media coverage and public debate concerning the management of forests.

In terms of marketing curricula of specific forest products, in 1994, products are discussed more often in the classroom than in to 1966 (Table 5). Specifically, the marketing of timber, lumber, logs, pulp, and value-added products are discussed by over
Table 5. Extent to which the marketing of the following forest products are taught

\begin{tabular}{|c|c|c|c|}
\hline \multirow[b]{2}{*}{ Type of product } & \multicolumn{2}{|c|}{$\begin{array}{l}\text { Percentage of } \\
\text { respondents }^{1}\end{array}$} & \multirow{2}{*}{$\begin{array}{c}\begin{array}{c}\text { Mean } \\
\text { response }^{2}\end{array} \\
1994\end{array}$} \\
\hline & 1966 & 1994 & \\
\hline \multicolumn{4}{|l|}{ Marketing of } \\
\hline Timber & 61 & 90 & 4.39 \\
\hline Lumber & 52 & 89 & 4.03 \\
\hline Pulpwood & 45 & 86 & 3.71 \\
\hline Logs & 37 & 91 & 4.18 \\
\hline Plywood & 31 & 75 & 3.39 \\
\hline Pulp & 15 & 73 & 3.01 \\
\hline Paper & 15 & 70 & 2.87 \\
\hline Value-added forest products ${ }^{3}$ & NA & 84 & 4.10 \\
\hline \multicolumn{4}{|l|}{ Other forest products } \\
\hline (e.g., chips, furniture) & 6 & 6 & 4.00 \\
\hline & $n=72$ & $n=102$ & $n=102$ \\
\hline
\end{tabular}

${ }^{1}$ Column totals exceed $100 \%$ due to multiple responses.

${ }^{2}$ Mean response based on a Likert scale anchored on 1 or "do not discuss" to 7 or "discuss in depth."

${ }^{3}$ Products not included in 1966 study.

$80 \%$ of the respondents. The most marked increase in frequencies is reported for the marketing of pulpwood, pulp, and paper; this can partly be explained by the market competition for raw material supply between paper and solid wood products and the greatly expanded range of paper products now available. Lastly, the recent evolution of engineered and specialized forest products may explain why a majority, or $84 \%$, of professors discuss the marketing of value-added wood products.

\section{Teaching methods and course materials}

Lecturing is the most common teaching method used by professors teaching marketing topics in their courses. This is followed in frequency by class discussion and participation, guest lectures from industry speakers, and case studies. In 1994 respondents integrated a greater variety of teaching methods into their curriculum as compared to their counterparts of 1966 (Table 6). For example, the number of professors using guest lectures from industry, case studies, and field trips has in some cases tripled in frequency since 1966.

Course materials used to teach marketing topics have shifted from texts to professional journals and publications (Table 7). Teachers are reporting more use of professional journals and industry publications as compared to texts in forest economics, forest products, forest products marketing, and marketing, opposite of reported results in the 1966 study. Rapid changes in manufacturing technologies, products, and research methods are likely to be influencing the increased use of journals in marketing-related courses.

\section{Location of marketing courses taken outside of forestry schools}

When asked if students took marketing courses outside of their school of forestry, $73 \%$ of the professors answered affirmatively. More specifically, $68 \%$ indicated that students took marketing in a business school and $21 \%$ took marketing in an economics department (Table 8). Note that the sum of these percentages exceeds $73 \%$ since many professors indicated that their students enrolled in marketing courses in business schools and economics departments in addition to the courses offered by their forestry schools. 


\begin{tabular}{|c|c|c|c|}
\hline \multirow[b]{2}{*}{ Teaching method } & \multicolumn{2}{|c|}{$\begin{array}{l}\text { Percentage of } \\
\text { respondents }^{1}\end{array}$} & \multirow{2}{*}{$\begin{array}{c}\begin{array}{c}\text { Mean } \\
\text { response }^{2}\end{array} \\
1994\end{array}$} \\
\hline & 1966 & 1994 & \\
\hline Lecture by instructor & 93 & 96 & 5.19 \\
\hline Class discussion and participation & 62 & 88 & 4.11 \\
\hline Guest lectures from industry & 39 & 77 & 3.09 \\
\hline Case studies & 25 & 74 & 3.33 \\
\hline Field trips & 22 & 58 & 2.91 \\
\hline Oral presentations by students ${ }^{3}$ & NA & 70 & 3.21 \\
\hline Projects $^{3}$ & NA & 68 & 3.22 \\
\hline Term papers ${ }^{3}$ & NA & 64 & 2.94 \\
\hline Guest lectures from government ${ }^{3}$ & NA & 53 & 2.03 \\
\hline Weekly assignments ${ }^{3}$ & NA & 48 & 2.47 \\
\hline \multirow[t]{2}{*}{ Simulations $^{3}$} & NA & 30 & 1.78 \\
\hline & $n=72$ & $n=102$ & $n=102$ \\
\hline
\end{tabular}

${ }^{1}$ Column totals exceed $100 \%$ due to multiple responses.

${ }^{2}$ Mean response based on a Likert scale anchored on 1 or "never use" to 7 or "use extensively."

${ }^{3}$ Teaching method not included in 1966 study.

\section{Marketing and Nonmarketing Groups}

The research findings discussed in the following sections represent responses from professors who discuss marketing topics in their courses (marketing group) and professors who do not discuss marketing topics in their courses (nonmarketing group). Comparisons are reported between the marketing and nonmarketing groups utilizing a two-tailed $t$-test statistic with an alpha of 0.05 .

\section{Importance of students taking various business courses}

Professors were asked how important it is for their students to take courses in the business-related disciplines of accounting, economics, finance, international business, human resources, marketing, operations management, and strategy. Economics, with a mean of 5.81 on a seven-point scale ranging from 1 or "not important" to 7 or "very important," (Table 9) is rated as the most important business-related topic for forestry students to enroll in. This is followed by operations management, human resources, strategy, and finance, with means of $5.11,4.92,4.64$, and 4.47 , respectively. The topic of marketing ranks sixth out of eight business-related disciplines with a reported mean of 4.39 .

There are two statistically significant differences, at the 0.05 confidence level, between the responses of the marketing and nonmarketing professors. The marketing group finds it more important for students to study accounting and finance as compared to the nonmarketing group. It may be that having addressed marketing, these professors are interested in having students acquire yet broader business knowledge in tangential business disciplines.

\section{Satisfaction with students' knowledge of various business topics}

Professors were asked about how satisfied they are with their students' knowledge of these same eight business-related topics. Respondents indicated (Table 9) they were most satisfied with students' knowledge of economics (mean response of 4.29 on a seven-point scale anchored on 1 or "not satisfied" to 7 or "very satisfied"). Operations management, with a mean of 4.09 , is the only other business-related topic that professors indicated some satisfaction with. Given that a mean of

\begin{tabular}{|c|c|c|c|}
\hline \multirow[b]{2}{*}{ Course materials } & \multicolumn{2}{|c|}{$\begin{array}{l}\text { Percentage of } \\
\text { respondents }{ }^{1}\end{array}$} & \multirow{2}{*}{$\begin{array}{c}\text { Mean } \\
\text { response }^{2} \\
1994\end{array}$} \\
\hline & 1966 & 1994 & \\
\hline Textbooks in forest economics & 61 & 67 & 3.00 \\
\hline Industry trade publications & 60 & 78 & 3.44 \\
\hline Professional journals & 41 & 84 & 3.78 \\
\hline Government publications & 38 & 76 & 3.34 \\
\hline Textbooks in forest products & 26 & 66 & 2.83 \\
\hline Industry publications & 21 & 79 & 3.58 \\
\hline \multicolumn{4}{|l|}{ Other (newsletters, stock and } \\
\hline Textbooks in marketing & 11 & 53 & 2.20 \\
\hline \multirow[t]{2}{*}{$\begin{array}{l}\text { Textbooks in forest product } \\
\text { marketing }{ }^{3}\end{array}$} & NA & 50 & 2.53 \\
\hline & $n=72$ & $n=102$ & $n=102$ \\
\hline
\end{tabular}

${ }_{1}^{1}$ Column totals exceed $100 \%$ due to multiple responses.

${ }^{2}$ Mean response based on a Likert scale anchored on 1 or "never use" to 7 or "use extensively."

${ }^{3}$ Course material not included in 1966 study.

Table 8. Location of marketing courses students take outside of forestry schools

\begin{tabular}{lcc}
\hline & \multicolumn{2}{c}{ Percentage of respondents } \\
\cline { 2 - 3 } School or department & $\mathbf{1 9 6 6}$ & $\mathbf{1 9 9 4}$ \\
\hline Business school & 62 & 68 \\
Economics department $^{\text {Building construction technology school }}{ }^{1}$ & 21 & 21 \\
Agricultural economics department $^{1}$ & NA & 2 \\
Architecture school $^{1}$ & NA & 2 \\
\hline & $n=72$ & 1 \\
\hline
\end{tabular}

${ }^{1}$ School or department not included in 1966 study.

4.0 represents the midpoint on the seven-point scale, or a neutral satisfaction value, respondents do not appear to be satisfied with students' knowledge of accounting, finance, international business, human resources, marketing, and strategy. Noteworthy is that the marketing group professors are found statistically, at the 0.05 level of confidence, to be significantly less satisfied than nonmarketing group professors with their students' knowledge of international business and human resources.

\section{Perceived importance industry places on various business topics}

The last question reported (Table 9) asked professors their perceptions of the importance that industry practitioners assign to student's having a knowledge of these eight business-related topics. Knowledge of operations management, human resources, economics, and marketing are ranked as the four most important areas of business knowledge, with respective means of 5.47, $5.08,5.05$, and 4.65 (seven-point scale anchored on 1 or "not important" to 7 or "very important"). Professors in the marketing group believe that industry places less importance on operations management and strategy than did the nonmarketing group. Conversely, the marketing group professors perceive that industry places greater importance on accounting.

\section{Professors' knowledge of forest products marketing}

When professors were asked to report their knowledge of forest products marketing, on a scale of 1 or "the same" to 7 


\begin{tabular}{|c|c|c|c|c|c|c|c|c|c|}
\hline \multirow[b]{3}{*}{ Topic } & \multicolumn{9}{|c|}{ Means 1} \\
\hline & \multicolumn{3}{|c|}{$\begin{array}{l}\text { Importance of students } \\
\text { taking courses in: }\end{array}$} & \multicolumn{3}{|c|}{$\begin{array}{c}\text { Satisfaction with } \\
\text { student's knowledge of }\end{array}$} & \multicolumn{3}{|c|}{$\begin{array}{l}\text { Perceived importance } \\
\text { industry places on } \\
\text { students' knowledge of }\end{array}$} \\
\hline & Group A & Group B & Group C & Group A & Group B & Group C & Group A & Group B & Group C \\
\hline Economics & 5.82 & 5.79 & 5.81 & 4.25 & 4.33 & 4.29 & 4.98 & 5.12 & 5.05 \\
\hline Operations management & 5.03 & 5.19 & 5.11 & 4.08 & 4.09 & 4.09 & $5.26^{2}$ & $5.69^{2}$ & 5.47 \\
\hline Human resources & 4.76 & 5.08 & 4.92 & $3.35^{2}$ & $3.82^{2}$ & 3.56 & 4.91 & 5.28 & 5.08 \\
\hline Finance & $4.74^{3}$ & $4.19^{3}$ & 4.47 & 3.88 & 3.92 & 3.90 & 4.58 & 4.42 & 4.51 \\
\hline Strategy and policy & 4.45 & 4.84 & 4.64 & 3.95 & 4.07 & 4.00 & $3.98^{3}$ & $4.62^{3}$ & 4.28 \\
\hline Marketing & 4.42 & 4.37 & 4.39 & 3.91 & 3.96 & 3.93 & 4.67 & 4.63 & 4.65 \\
\hline Accounting & $4.26^{2}$ & $3.59^{2}$ & 3.93 & 3.59 & 4.01 & 3.77 & $4.41^{2}$ & $3.92^{2}$ & 4.18 \\
\hline International business & 4.11 & 4.10 & 4.11 & $3.20^{2}$ & $3.66^{2}$ & 3.40 & 3.99 & 4.18 & 4.08 \\
\hline Scale & \multicolumn{3}{|c|}{$\begin{array}{l}1=\text { "not important" } \\
7=\text { "very important" }\end{array}$} & \multicolumn{3}{|c|}{$\begin{array}{c}\text { 1="'not satisfied" } \\
7=\text { "very satisfied" }\end{array}$} & \multicolumn{3}{|c|}{$\begin{array}{l}1=\text { "not important" } \\
7=\text { "very important" }\end{array}$} \\
\hline
\end{tabular}

${ }^{1}$ Group A ( $\left.n=102\right)$ discuss forest products marketing in their courses. Group $\mathrm{B}(n=102)$ do not discuss forest products marketing in their courses. Group C $(n=204)$ represents Group A and Group B combined.

${ }^{2}$ Statistical difference exists between Groups A and B means at $\alpha=0.05$ using a two-tailed $t$-test statistic.

${ }^{3}$ Statistical difference exists between Groups A and B means at $\alpha=0.01$ using a two-tailed $t$-test statistic.

or "much greater," relative to three years ago, there is a significant difference, at the 0.01 confidence level, between the marketing and nonmarketing groups. The mean response of the marketing group professors is 4.09 , with 90 percent of the professors indicating that their knowledge of forest products marketing has increased over the previous three years. On the other hand, the reported mean response for the nonmarketing group is 2.80 , suggesting only a marginal increase in their knowledge of forest products marketing.

If professors reported that their knowledge of forest products marketing had increased over the past three years, they were further probed as to the causes for this increase. The three most commonly cited reasons given (Table 10) are independent study or research, experience acquired through conferences or seminars, and working with other faculty. In terms of differences between the marketing and nonmarketing groups, two relationships are statistically significant. For the marketing group, the most common means by which their forest products knowledge has increased is through individual study or research, with a mean of 4.63 (seven-point scale anchored on 1 or "not important" to 7 or "very important"). This is significantly different at the 0.01 level when compared to the nonmarketing group's mean of 3.63 for independent study. On the other hand, the nonmarketing group reports that working with other faculty is the number one reason for their increase in marketing knowledge, marginally significant at the 0.10 confidence level from the mean response of the marketing group. Intuitively, this makes sense; the marketing group probably possesses the knowledge to "go it alone" through independent research whereas the nonmarketing group probably assimilates marketing knowledge through working with others who have knowledge of and training in the area.

When questioned whether they thought their knowledge of forest products marketing would be greater over the next three years, professors belonging to the marketing group have a mean response of 4.27 , while the nonmarketing group mean response is 2.80 (seven-point scale anchored on 1 or "the same" to 7 or "much greater"). This is significant at the 0.01 confidence level, suggesting that the marketing group is much more expectant that they will acquire additional knowledge about forest products marketing. Once again, $90 \%$ of the marketing group professors predicted that their forest products marketing knowledge would increase over the next three years.

\section{Student access to marketing courses outside of forestry schools}

When asked to appraise their students' access to marketing courses outside their school of forestry, professors reported that students generally did not lack access to such courses. Student access to marketing courses outside of their forestry school increased as the student's degree level (i.e. baccalaureate, master's, doctoral) increased (Table 11).

\section{Satisfaction with students' forest products marketing knowledge}

Having investigated various aspects of forest products marketing, it was appropriate to explore how satisfied professors were with their students' forest products marketing knowledge. Mean responses are shown (Table 11). Assuming a neutral mean of 4.0, midpoint on a seven-point scale anchored on 1 or "not satisfied" to 7 or "very satisfied," the findings indicate that professors are neither dissatisfied nor satisfied. The 204 responses suggest professors are slightly dissatisfied with students' knowledge of forest products marketing at the baccalaureate level while somewhat satisfied with master's and doctoral students' knowledge.

\section{Industry's satisfaction with students' forest products marketing knowledge}

When asked about their perceptions of how satisfied employers are with students' knowledge of forest products (Table 11), respondents belonging to the nonmarketing group report higher means. This reflects that at all degree levels, nonmarketing group professors perceived the industry to be more satisfied with students' forest product marketing knowledge than marketing group professors.

\section{Students' ability to apply forest products marketing concepts}

Professors were asked the degree to which their students are able to apply the concepts of forest products marketing as tools and techniques needed in the workplace. The reported mean 
Table 10. Forestry professors' reasons as to why their forest products marketing knowledge is greater ${ }^{1}$

\begin{tabular}{|c|c|c|c|}
\hline & \multicolumn{3}{|c|}{ Means $^{2,3}$} \\
\hline & Group A & Group B & Group C \\
\hline Independent study or research & $4.63^{4}$ & $3.63^{4}$ & 4.23 \\
\hline Experience acquired through conferences or seminars & 4.00 & 3.95 & 3.98 \\
\hline Working with other faculty & $3.79^{5}$ & $4.30^{5}$ & 3.99 \\
\hline Greater student interest & 2.62 & 2.62 & 2.62 \\
\hline Encouragement from government funding & 2.08 & 2.11 & 2.09 \\
\hline Encouragement from industry funding & 1.96 & 2.14 & 2.04 \\
\hline
\end{tabular}

${ }^{1}$ Means of 155 respondents indicating their forest products marketing knowledge is greater than 3 years ago.

${ }^{2}$ Mean response based on a Likert scale anchored on 1 or "not important" to 7 or "very important."

${ }^{3}$ Group A $(n=92)$ discuss forest products marketing in their courses. Group B $(n=63)$ do not discuss forest products marketing in their courses. Group C $(n=155)$ represents Group A and Group B combined.

${ }^{4} \mathrm{~A}$ statistical difference exists between Groups A and B means at $\alpha=0.01$ using a two-tailed $t$-test statistic.

${ }^{5} \mathrm{~A}$ statistical difference exists between Groups A and B means at $\alpha=0.10$ using two-tailed $t$-test statistic.

Table 11. Forestry professors' perceptions of student access to and satisfaction with forest products marketing knowledge

$$
\text { Means } \mathbf{s}^{1,2}
$$

\begin{tabular}{|c|c|c|c|c|c|c|c|c|c|}
\hline & & & & & & & & & \\
\hline \multirow[b]{2}{*}{ Degree level } & \multicolumn{3}{|c|}{$\begin{array}{c}\text { Student access to } \\
\text { marketing courses } \\
\text { outside forestry schools }\end{array}$} & \multicolumn{3}{|c|}{$\begin{array}{c}\text { Satisfaction with } \\
\text { students' forest products } \\
\text { marketing knowledge }\end{array}$} & \multicolumn{3}{|c|}{$\begin{array}{l}\text { Industry's satisfaction with } \\
\text { students' forest products } \\
\text { marketing knowledge }\end{array}$} \\
\hline & Group A & Group B & Group C & Group A & Group B & Group C & Group A & Group B & Group C \\
\hline Baccalaureate & 5.06 & 4.94 & 5.01 & 3.74 & 3.80 & 3.77 & 3.85 & 4.01 & 3.92 \\
\hline Master & 5.65 & 5.42 & 5.54 & 4.23 & 4.25 & 4.24 & 4.16 & 4.38 & 4.26 \\
\hline Doctoral & 5.83 & 5.38 & 5.61 & 4.35 & 4.23 & 4.30 & 4.15 & 4.39 & 4.34 \\
\hline Scale & \multicolumn{3}{|c|}{$\begin{array}{l}1=\text { "no access" } \\
7=" \text { full access" }\end{array}$} & \multicolumn{3}{|c|}{$\begin{array}{c}1=\text { "not satisfied" } \\
7=\text { "very satisfied" }\end{array}$} & \multicolumn{3}{|c|}{$\begin{array}{c}1=\text { "not satisfied" } \\
7=\text { "very satisfied" }\end{array}$} \\
\hline
\end{tabular}

${ }^{1}$ Group A $(n=102)$ discuss forest products marketing in their courses. Group B $(n=102)$ do not discuss forest products marketing in their courses. Group $\mathrm{C}(n=204)$ represents Group A and Group B combined.

${ }^{2}$ No differences between means for Group A and Group B are found to be statistically significant across each question and degree level.

for the marketing group is 4.13 (seven-point scale anchored on 1 or "never" to 7 or "extensively"), while the mean for the nonmarketing group is 3.67 . The difference between these two groups is significant at the 0.05 level of confidence. This difference is interesting because it implies that professors belonging to the marketing group are more confident that their students can successfully parlay marketing training into useful skills in the workplace.

\section{Assessment of forest products marketing in the future}

The final question was an open-ended question asking professors to speculate on the future of forest products marketing at their institution. A total of 138 professors or $68 \%$ wrote comments in the area provided. The professors' comments were interpreted and coded by the authors using a scale anchored on 1 or "very pessimistic future" to 5 or "very optimistic future." The reported mean of 3.32 indicates that professors foresee a positive future for forest products marketing at their institutions.

\section{Discussion}

In terms of the longitudinal insights sought through replicating Rich's (1966) study, the findings of this study do not suggest major differences in the status of marketing education at schools of forestry. Given the pervasive dialogue in the forest products industry about the importance of marketing, the implied hypothesis of this study was that the findings would reveal an expanded role of marketing in forestry education. Nonetheless, the new areas of inquiry investigated in this study offer unique insights. Forestry school professors generally agree that it is important that students receive training in all disciplines of business, including operations management, human resources, strategy, finance, marketing, international business, and accounting. Forestry school professors are also somewhat satisfied with their students' economics education yet are slightly dissatisfied with students' other business-related education. This suggests that the academic community should provide overarching contextual knowledge of these basic business disciplines to their students.

Findings show that when asked about the marketing training that students receive, professors report much more emphasis on economics-based topics such as the economics of market demand and foreign trade. Unfortunately, relatively less emphasis is reported on core marketing topics such as product, price, and promotion. While both marketing and economics address important issues, the essential difference is that the unit of analysis in marketing is generally the customer whereas in economics the unit of analysis is generally the industry. As such, marketing is most fundamentally concerned with the design of a customer-oriented marketing mix (product, price, promotion, and distribution) in order to sustain a competitive advantage for the firm. It is hoped that future curricula will emphasize both marketing and economics so as to offer students the exposure and knowledge necessary for successfully competing in the marketplace and maximizing firm performance.

Despite the less than overwhelming indicators of satisfaction with students' marketing knowledge, professorial perceptions regarding their own future acquisition of marketing knowledge is optimistic. For professors who discuss marketing topics in their courses, an impressive $90 \%$ reported that their knowledge of forest products marketing would continue to increase during the next three years. As suggested by Hill (1994), 
"in business, a little knowledge is indeed a dangerous thing." This is because shallow or incomplete explanations, ones without the accompanying complexities, can paint an inexact portrait. These findings are encouraging because they suggest that professors strive to stay abreast of changes and participate fully in the evolving discipline of forest products marketing. From the student perspective, this is particularly important because it may imply that professors are willing to practice their own form of a market orientation for their "customers," their students, in developing marketing programs that enable forestry students to be better trained and more purposeful.

\section{References}

Armstrong, J.S. and T.S. Overton. 1977. Estimating nonresponse bias in mail surveys. J. Marketing Res. 14(3): 396-402.

Bowyer, J.L. 1991. Undergraduate education for the forest products industry. Wood Fiber Sci. 23(4): 607-617.

Bratkovich, S.M. and L.E. Miller. 1993. Perceived educational needs of innovative Ohio sawmill users. For. Prod. J. 43(3): 35-40.

Cassens, D.L. and J.P. Bradtmueller. 1996. Characterization of the custom woodworking industry. For. Prod. J. 46(5): 29-36.
Fischer, B.C. and J.T. O'Leary. 1988. Continuing education needs of Indiana foresters - a preliminary analysis. Purdue University, Department of Forestry and Natural Resources, Indiana Forest Products Marketing and Wood Utilization Report, Bulletin 194: 3-5.

Forbes, R.D. 1920. Specialization vs. generalization in forestry education. J. For. 18: 383-390.

Hill, C.W.L. 1994. International business: Competing in the global marketplace. Richard D. Irwin, Inc., Homewood, Illinois. 615 p. Kotler, P. 1991. Marketing management: Analysis, planning, implementation, and control. Prentice Hall, Inc., Englewood Cliffs, New Jersey.756 p.

Naysmith, J.K. and J.J. Crichlow. 1995. Educating the 21 st century forester. For. Chron. 71(3): 345-352.

Nordin, V. J. 1984. Canadian schools of forestry - Retrospect and prospect. University of Alberta Forest Industry Lecture Series No. 12. University of Alberta, Edmonton. 32 p.

Rich, S.F. 1966. The study of marketing in schools of forestry. J. For. 64(8): 527-530.

Slater, S.F. and J.C. Narver. 1994. Does competitive environment moderate the marketing orientation-performance relationship? J. Marketing 58(1): 46-55. 